\title{
Bilateral transient radial nerve palsies in an infant after cardiac surgery
}

\author{
N obuaki Shime MD PhD,* \\ Yuko Kato $M D, *$ \\ Yoshifumi Tanaka M D PhD,* \\ Wook-Cheol Kim MD PhD †
}

Purpose: To describe the case of an infant who suffered bilateral transient radial nerve palsies after cardiac surgery.

Clinical features: A one-month-old baby was found to have bilateral wrist and finger drop after the removal of splints that has been applied to the right hand for 14 days and to the right hand for six days during perioperative management of Blalock-Taussig shunt surgery. The hand splints had been applied to the forearms with adhesive silky tape to keep peripheral vascular lines in place. The patient also suffered from several episodes of cardiogenic shock, hypoxemia and generalized edema relating to cardiac dysfunction during this fine period. Given the findings of no impairment of median or ulnar nerves and brachioradial muscle, it was suspected that bandaging with adhesive tapes caused peripheral radial nerve damage at the level of posterior interosseus nerve on forearm. Diminished oxygen delivery and edema may additionally have contributed to peripheral nerve ischemia. The aforementioned neurologic symptoms resolved spontaneously after several days.

Conclusion: Prolonged compression by bandaging of splints on forearm may have resulted in ischemic damage to the posterior interosseus nerve branch combined with extensor carpi radialis longus nerve branch of the radial nerve. We should attempt to reduce the frequency and duration of splinting of the extremities, especially in sedated, paralyzed babies, given the potential risk of compression neuropathy.

O bjectif : D écrire le cas d'un enfant qui a souffert d'une paralysie bilatérale transitoire du nerf radial à la suite d'une intervention cardiaque.

É léments cliniques : Un bébé d'un mois avait les mains et les doigts tombants après le retrait d'une attelle appliquée à la main droite pour 14 jours et à la main gauche pour six jours pendant le traitement périopératoire d'une anastomose de Blalock-Taussig. Les attelles de la main ont été appliquées avec un ruban de soie adhésif afin de maintenir en place les cathéters vasculaires périphériques. Le patient a aussi souffert de quelques épisodes de choc cardiogénique, d'hypoxémie et d'œ dème généralisé relié au dysfonctionnement cardiaque pendant cette période. Comme aucune atteinte des nerfs médian ou cubital ni du muscle long supinateur n'a été décelée, on a pensé que le bandage avec le ruban adhésif avait causé une lésion périphérique du nerf radial au niveau du nerf interosseux postérieur de l'avant-bras. L'apport réduit d'oxygène et la présence d'œ dème ont pu aussi contribuer à l'ischémie du nerf périphérique. Les symptômes neurologiques susmentionnés ont disparus spontanément après quelques jours.

Conclusion : La compression prolongée provoquée par le bandage d'attelles à l'avant-bras a pu causer une lésion ischémique dans le territoire du nerf interosseux postérieur, et dans la zone du muscle premier radial innervé par un rameau du nerf radial. II faut, autant que possible, réduire la fréquence et la durée du bandage des extrémités, surtout chez des bébés sous sédation et paralysés, étant donné le risque potentiel de neuropathie par compression.

From the D epartment of Anesthesiology and Intensive Care,* and D epartment of O rthopedics, $†$ Kyoto Prefectural U niversity of M edicine, K yoto, Japan.

A ddress correspondence to: Dr. N obuaki Shime, D epartment of Anesthesiology and Intensive Care, Kyoto Prefectural U niversity of M edicine, Kawaramachi-H irokoji, Kamigyo-ku, Kyoto, Japan. Phone: +81-75-251-5633; Fax: +81-75-251-5843;

E-mail: shime@koto.kpu-m.ac.jp

A ccepted for publication October 13, 2000. 
ERIPH ERAL nerve palsy is a well-described complication of general anesthesia. ${ }^{1,2}$ External nerve compression from inappropriate positioning in sedated and paralyzed patients is believed to be a cause of ischemic nerve injury. ${ }^{3}$ Given their small size and inability to respond to sensory changes such as numbness or paresthesia, infants are at much greater risk for developing compression neuropathy. We encountered bilateral radial nerve palsies in an infant after undergoing BlalockT aussig shunt surgery in the setting of prolonged forearm bandages with splints.

\section{Case report}

A 27-day-old male, $3800 \mathrm{~g}$, baby was admitted to our Pediatric Intensive $\mathrm{C}$ are U nit (PICU) after left modified Blalock-Taussig shunt surgery. Fourteen days later, he was noted to have radial nerve palsies associated with prolonged attachment of splints to both forearms.

Perioperative course of the two surgeries No abnormalities in the patient's nervous system had been detected preoperatively. An intravenous catheter was placed in the right dorsal metacarpal vein preopera tively. $\mathrm{H}$ is right hand had been bandaged by a silky elas tic adhesive tape (Silkypore ${ }^{\circledR}$, Sumitomo-3M, Tokyo, Japan) with an aluminium-based splint (Alfence ${ }^{\circledR}$, Alcare, Tokyo, Japan) to ensure sufficient drip infusion (Figure 1). D uring the surgery, he was positioned with his bilateral shoulder joints abducted to 90 and elbow joints flexed to 90 with soft pads placed beneath the upper limbs to avoid excess shoulder extension.
After admission to the PICU, sudden bradycardia < $20 \mathrm{bpm}$ and hypotension $<20 \mathrm{mmH}$ g due to acute cardiac dysfunction occurred. Although the patient was resuscitated, higher doses of inotropics including adrenaline were needed subsequently for ventricular failure. Peritoneal dialysis was performed for oliguria and generalized edema. Laboratory data revealed no increases in muscle-derived enzymes or creatinine levels. The patient had been receiving artificial ventilation under continuous sedation with midazolam, fentanyl, and vecuronium. A blood pressure cuff was attached in both arms at approximately every two hours to check the difference relating to left-subclavian shunting.

Seven days after the first surgery, he underwent a second surgery for replacement of the shunt graft with a smaller size in order to reduce pulmonary blood flows and relieve ventricular overload. An arterial line was placed in the left radial artery, and the left hand was bandaged by adhesive tape, with a splint similar to the one primarily applied to the right hand, in order to monitor the appropriate arterial waveform. The patient suffered an episode of transient severe hypoxemia $\left(\mathrm{SpO}_{2}\right.$ below $\left.60 \%\right)$ during the second surgery. The postoperative general status was uneventful. No abnormality was detected in his level of consciousness after the withdrawal from sedatives.

\section{Detection of radial nerve palsy}

Thirteen days after the first surgery, the bilateral hand splints were removed. The splints remained attached for a total of 14 days on the right hand and six days on the left. When the splints were removed, bilateral wrist

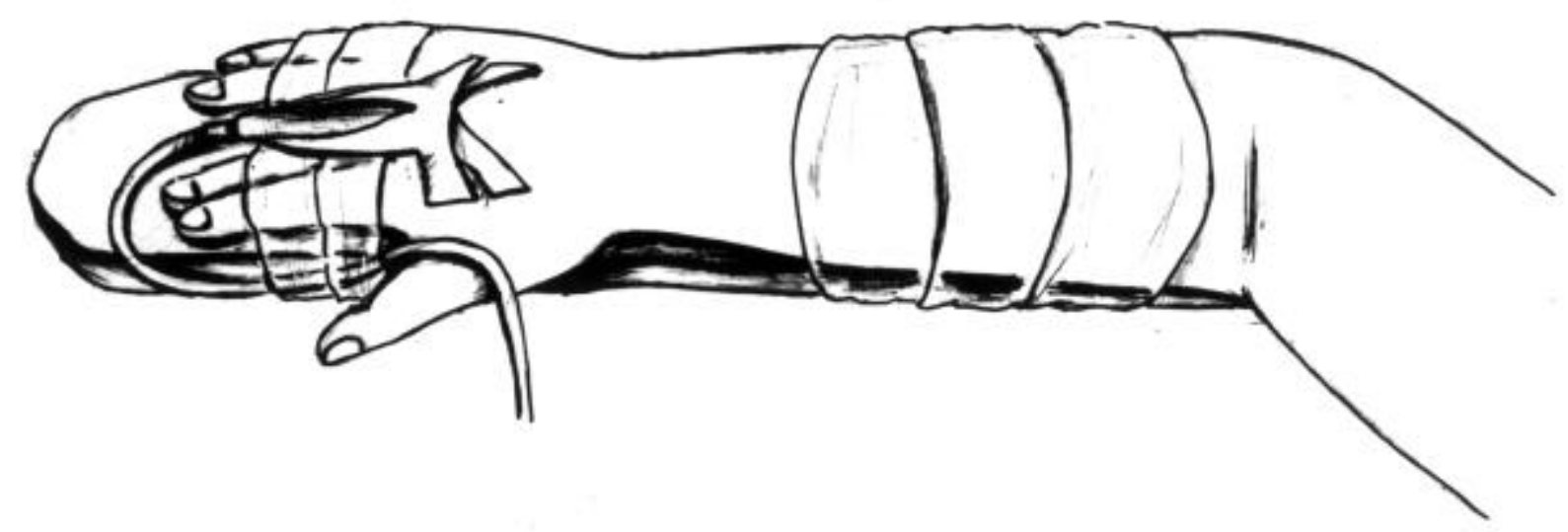

FIGURE 1 H and splinting

The baby is attached an anterior arm splint using silky elastic adhesive tapes. 


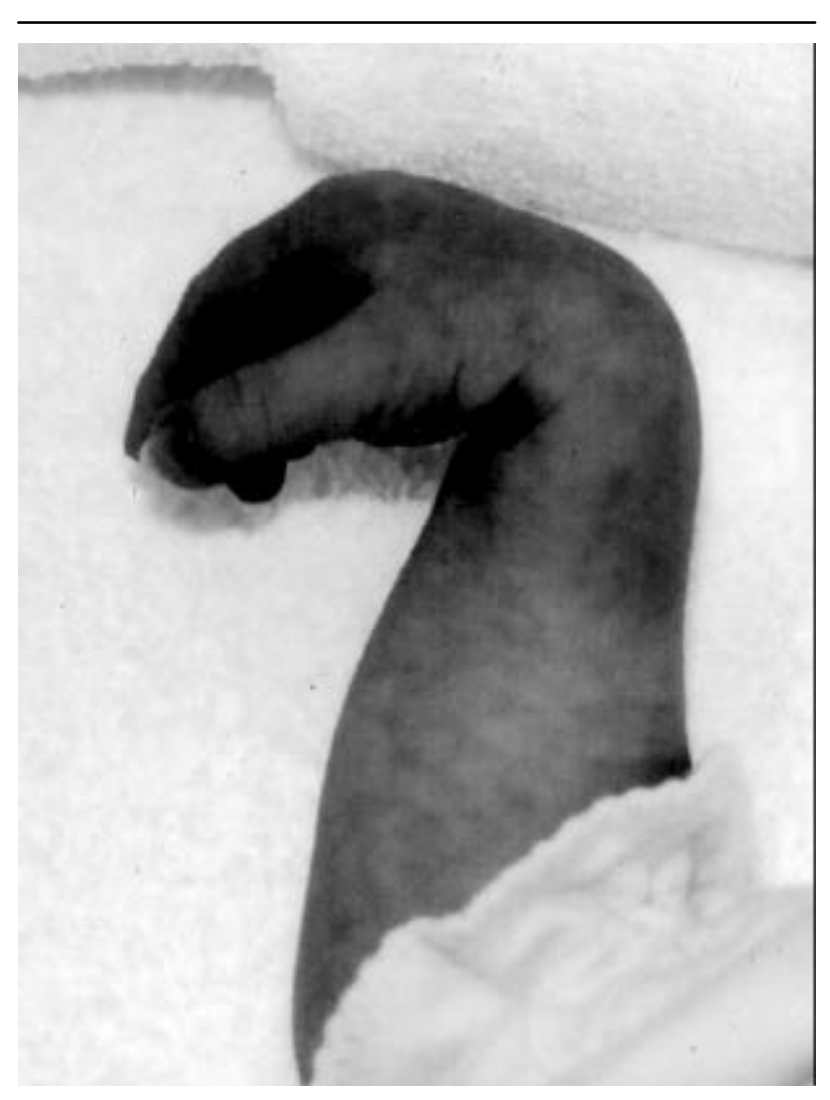

FIGU RE 2 Right dropped hand and fingers

The baby's hand and fingers dropped under gravity, and did not extend spontaneously.

and finger drop was noted (Figure 2). Extension movements of the wrist and fingers were completely absent. Elbow movements and flexion movements in the fingers were intact.

Orthopedic consultation was obtained and a diagnosis of radial nerve injury was made. The possibility of brachial plexus or proximal radial nerve injury was excluded because of intact median nerve and brachioradialis muscular function. It was suspected that the radial nerve had been damaged at the level of the posterior interosseous nerve because the adhesive tape compressed the posterior forearms. No swelling was detected, however, in the area of the bandages. The precise site of injury was not determined by electrodiagnostic studies, given the invasiveness of their studies in an ill, postoperative infant. Examinations of sensory fibers with pin-click testing of the forearms shoved no detectable abnormalities due to vague responses.

Three days later, right wrist extension movement was detected with grade 2/ 5 to $3 / 5$ power. Clinical recovery, with the $5 / 5$ extension on the right hand, was detected on the 4th day after the initial appearance of palsy, followed by recovery of the left hand on the 9 th day.

\section{Discussion}

Compression damage to the radial nerve rarely occurs during anesthesia without prolonged, severe mechanical pressure. ${ }^{4} \mathrm{H}$ owever, compression radial neuropathy in neonates has been reported in association with less severe stresses from frequent application of an arterial blood pressure cuff ${ }^{5}$ or compressions during failure of progression of delivery, ${ }^{6}$ suggesting greater vulnerability of babies.

The site of injured radial nerve can be diagnosed by assessing clinical signs. ${ }^{7}$ In our patient, the presence of impaired extension of both wrists and fingers, with normal movement at the elbow joints and normal finger flexion indicates peripheral radial nerve injury at or distal to the spiral groove. The prolonged splinting of the hands was suspicious for causing compression nerve damage. An elevation in pressure of the posterior compartment of the forearm due to tightening by adhesive tape could have resulted in damage in the posterior interosseus nerve as it travels through the spinator muscle. 7,8 The presence of wrist drop might also indicate concurrent damage to the extensor carpi radial is longus nerve. ${ }^{9}$ The other possible site of damage was at the posterior part of the humerus, due to pressure from inflation of the blood pressure cuff or the edge of the splint, causing similar symptoms. If we had obtained sensory examination or electrodiagnostic studies, those would have been helpful for determination of the precise site of injury.

Repeated episodes of diminished peripheral oxygen delivery in this patient with cyanotic, congenital cardiac disease are also likely to have exacerbated nerve damage. ${ }^{2}$ Interstitial edema occurring during and after cardiopulmonary bypass or during venous infusion would have resulted in additional increase in compression of the nerve fibres. ${ }^{10}$ The presence of bilateral occurrence of nerve injury suggests the participation of these factors.

It should be noted that nerve injury in children has the potential to cause psychological trauma for parents, despite the fact that spontaneous remission is the usual outcome. ${ }^{2}$ We should attempt to reduce the frequency and duration of splinting of the extremities, especially in sedated, paralyzed babies.

\section{References}

1 Perreault L, D rolet $P$, Farny J. U Inar nerve palsy at the elbow after general anaesthesia. Can J Anaesth 1992; 39: 499-503. 
2 Muller-Vahl H, M unte TF, Vahl CF. Postoperative ulnar nerve palsy: is it an unpreventable complication? Anesth Analg 1993; 77: 404-5.

3 Ciulla TA, Frederick AR Jr, K elly C, A mrein R. Postvitrectomy positioning complicated by ulnar nerve palsy. Am J O phthalmol 1996; 122: 739-40.

4 Guzman F, N aik S, Weldon OG, H ilton CJ. Transient radial nerve injury related to the use of a self retaining retractor for internal mammary artery dissection. J Cardiovasc Surg 1989; 30: 1015-6.

5 Tollner $U$, Bechinger $D$, Pohlandt $F$. Radial nerve palsy in a premature infant following long-term measurement of blood pressure. J Pediatr 1980; 96: 921-2.

$6 \mathrm{H}$ ayman $\mathrm{M}, \mathrm{R}$ oland $\mathrm{EH}, \mathrm{H}$ ill A. N ewborn radial nerve palsy: report of four cases and review of published reports. Pediatr N eurol 1999; 21: 648-51.

7 Carlson N, Logigian EL. Radial neuropathy. N eurol Clin 1999; 17: 499-523.

8 Eaton CJ, Lister GD. Radial nerve compression. $\mathrm{H}$ and Clin 1992; 8: 345-57.

9 H ashizume H, N ishida K, N anba Y, Shigeyama $Y$, I noue $\mathrm{H}$, M orito $\mathrm{Y}$. $\mathrm{N}$ on-traumatic paralysis of the posterior interosseous nerve. J Bone Joint Surg Br 1996; 78: 771-6.

10 Salisoury RE, Dingeldein GP. Peripheral nerve complications following burn injury. Clin Orthop 1982; 163: 92-7. 